J. Product. \& Dev., 24(1): $37-61(2019)$

\title{
EFFECT OF PLANTING DATE, IRRIGATION LEVEL AND FOLIAR SPRAY WITH CALCIUM AND/OR BORON ON POTATO CROP PERFORMANCE 2. YIELD AND ITS COMPONENTS, CRACKING PHENOMENON AND TUBER QUALITY
}

\section{Fawzy Y. O. Mansour* and Hanan M. Abu El-Fotoh**}

*Hort. Res. Inst., ARC. Giza, Egypt

${ }^{* *}$ Soil, Water and Environ. Res. Inst. ARC, Giza, Egypt.

\section{ABSTRACT}

A filed experiment was carried out during the two successive seasons of 2016/2017 and 2017/2018 at the experimental farm of ElGemmeiza, Agric Res. Station, ARC, Gharbiya Governorate (Middle Nile Delta, Egypt) to study the effect of planting date $\left(20^{\text {th }}\right.$ September (Sep) and 10 $0^{\text {th }}$ October (Oct), irrigation water level at 50, 75 and $100 \%$ of filed capacity (FC) and two foliar spray with $\mathrm{Ca}(1 \%)$ as calcium chloride and/or boron (60 ppm) as boric acid besides unsprayed treatment (control), and their interactions on yield and its components, tuber cracking and tuber quality under clayey soil conditions using flood irrigation system. The adopted treatments were arranged in a split - split plot design with three replicates. The planting dates were arranged in the main plots, irrigation water quantities were arranged in the sub plots, while Ca and/or B foliar sprays were randomly distributed in sub - sub plots.

The obtained results indicate that, the tertiary interaction of planting on $10^{\text {th }}$ Oct. , irrigation at $100 \%$ FC and sprayed plants with $C a+B$ resulted in higher values of total tuber yield, average tuber weight, number of tuber № plant ${ }^{-1}$, tuber yieldplant ${ }^{-1}$,N, K, $C a$ and $B$ contents and DM percentages in $1^{\text {st }}$ and $2^{\text {nd }}$ seasons. Total carbohydrates were the highest with the interaction of planting on $10^{\text {th }}$ Oct. and irrigating at $100 \% \mathrm{FC}$ and sprayed plants with B. The increases in total tuber yield were about 253.75 and $177.82 \%$ for tertiary interaction of planting on $10^{\text {th }}$ Oct, irrigation at $100 \% \mathrm{FC}$ and sprayed with $\mathrm{Ca}+\mathrm{B}$ over the interaction of planting on $20^{\text {th }}$ Sep , irrigation with 50\%FC and unsprayed plants, in the $1^{\text {st }}$ and $2^{\text {nd }}$ 
seasons, respectively. As for tuber cracking \%, the lowest values were obtained with the tertiary interaction of planting on $10^{\text {th }}$ Oct, irrigation with $75 \% F C$ and sprayed with $C a+B$ (11.37 and 10.41 $\%)$ in the $1^{\text {st }}$ and $2^{\text {nd }}$ seasons, respectively, while the highest values were obtained with the tertiary interaction of planting on $20^{\text {th }} \mathrm{Sep}$, irrigation at $100 \%$ FC and without $C a$ and B (25.38 and $26.57 \%$ in the $1^{\text {st }}$ and $2^{\text {nd }}$ seasons, respectively).

Conclusively, under similar conditions it could be concluded that , the tertiary interaction of planting on $10^{\text {th }}$ Oct, irrigation at $100 \%$ $F C$ and sprayed plants with $C a+B$ was superior for enhancing both total tuber yield and quality. Furthermore, on reducing tuber cracking, combination of planting on $10^{\text {th }}$ Oct, irrigation at $75 \%$ FC and spraying the plants with $C a+B$ is recommended.

Key word: Potato tuber yield $\&$ its attributes, planting date, irrigation level, tuber quality, Ca and B foliar sprays, tuber cracking phenomenon.

\section{INTRODUCTION}

The increase in human population is stimulating the increase in demand for good quality potato tubers. In addition to quantity, potato quality is an important factor based on consumer demand. Potato quality is determined by tuber size, tuber weight and cracking- free etc. All these parameters collectively determine the marketable tuber yield.

Planting date is considered very important to take the full advantage of the short growing period. Since tuberization rate in potato declines above a temperature of $17^{\circ} \mathrm{C}$, increasing temperature may lead to reduced yields. Determining the optimum date of planting is not only important for yield but also to ensure better tuber quality (Dash et al. 2018). In natural environment plants are subjected to many stresses that have a great impact on development and finally yield of the crops. In this respect, Sandhu et al. 2013, Thongam et al. 2017 and Dash et al. 2018 stated that planting date had significant effects on yield and tuber quality of potato.

Egypt suffers from the limited natural water resources for irrigation the cultivated area besides the other water - consuming activities. Furthermore, irrigation water quantity is considered as one of the main factors that greatly affect plant growth and yield. So, efforts should be directed to optimize water 
requirements and improved water productivity for all crops including potato. In addition, yield response to irrigation of different crops is of major importance in production planning where water resources are limited. Levy et al. 2013 reported that abiotic stress factors, such as drought, have severe, adverse effects on potato growth and yield, and regular water supply is necessary to achieve a high quality yield.. In connection, Erdem et al. (2006) reported that furrow and drip irrigation methods had no significant effect on tuber yield. Irrigation regimens influenced tuber yield $(\mathrm{P}<0.05)$ and the highest tuber yield was registered for $30 \%$ irrigation regimen comprised 35.13 - $44.56 \mathrm{t} \mathrm{ha}^{-1}$, comparable with irrigating as 50 or $70 \%$ of the available soil water was consumed. In Egypt, Farrag et al. (2016) found that different irrigation levels vis 50, 75 and $100 \%$ of irrigation requirements, under drip irrigation, significantly affected potato vegetative growth, tuber yield and nutrients content $(\mathrm{N}, \mathrm{P}$ and $\mathrm{K})$, and Increasing irrigation requirements for potato crop from $50 \%$ to $100 \%$ enhanced total and marketable yield. Furthermore, Badr et al. (2012) Irrigated potato under drip irrigation with different levels e.g. 40, 60, $80,100 \%$ evaporation) resulted in a significant increase in the growth parameters, yield of tubers in particular, by increased irrigation level. In addition, Cantorea et al.(2014) reported that Water stress due to $50 \%$ irrigation level, significantly affected yield response, and the marketable yield decrement of $25.9 \%$ was observed, compared with $100 \%$ full irrigation level.

Calcium plays an important role in tuber quality by forming part of the membrane cell wall structures (Kleinhenz and Palta 2002). In connection, Palta (1996) reported that potato tuber quality can be enhanced by increasing $\mathrm{Ca}$ content of the tubers. Gumede (2017) found that yield and quality of potatoes will be affected by the Ca application level. In this regard, Chowdhury 2017, Simango and Walls 2017, Tantawy et al. 2017 and Singh et al. 2018 indicated that sprayed potato plants with calcium and/or boron increased tuber yield and improving quality as well.

Therefore, the aim of the present work is to study the proper planting date, irrigation level, and foliar spray with calcium or/and boron for enhancing potato productivity, mitigating tuber cracking disorder and improving tuber quality of potato grown on a clayey soil at Gemmeiza area under furrow irrigation system.

\section{MATERIALS AND METHODS}

A filed experiment was carried out in the successive winter seasons of 2016/2017 and 2017/2018 at the experimental Farm El- Gemmeiza, Agric Res. 
Station, ARC, Gharbiya Governorate (Middle Nile Delta, Egypt) to study the effect of planting date, irrigation water level and foliar sprays of $\mathrm{Ca}$ and/or $\mathrm{B}$ and their interactions on potato productivity, yield components, tuber cracking phenomenon and other tuber quality traits under furrow irrigation. The soil in the experimental site is clayey in texture with bulk density, field water capacity and available water values, in the $60 \mathrm{~cm}$ depth of the soil profile, comprised $1.25\left(\mathrm{gcm}^{-3}\right), 43.01$ and $17.92 \%$ by mass, respectively.

The mechanical and chemical analysis of the used soil are presented in Table (A). Particle size distribution was carried out using the method of Piper (1950). Calcium carbonate was determined using Collins calcimeter according to Wright (1939). Organic matter was assayed according to method of Walkley (1947). Total available nitrogen was determined using the microkjeldohl and Phosphorus was determined according to methods as described by Chapman and Pratt (1961). Potassium was determined using Flam photometeric method described Piper (1938). Available B was determine by Bingham (1982). pH value was measured in the soil past using Bechman $\mathrm{pH}$ meter.

Table (A). The mechanical and chemical analysis of the experimental soil

\begin{tabular}{|l|c|c|}
\hline Parameters & \multicolumn{2}{|c|}{ Values } \\
\hline 1. Mechanical analysis & $\begin{array}{c}\text { First } \\
\text { season }\end{array}$ & $\begin{array}{c}\text { Second } \\
\text { Season }\end{array}$ \\
\hline Corse sand (\%) & 1.60 & 1.50 \\
\hline Fine sand (\%) & 12.91 & 14.4 \\
\hline Silt (\%) & 37.23 & 35.9 \\
\hline Clay (\%) & 40.82 & 43.0 \\
\hline $\mathrm{CaCO}_{3}(\%)$ & 3.90 & 3.20 \\
\hline Organic matter (\%) & 1.57 & 1.98 \\
\hline Texture class & Silty clay loam & \\
\hline 2. Chemical analysis & & 35 \\
\hline Available nitrogen (ppm) & 33 & 8.8 \\
\hline Available phosphorus (ppm) & 8 & 440 \\
\hline Available potassium (ppm) & 420 & 0.12 \\
\hline Available boron $(\mathrm{ppm})$ & 0.10 & 8 \\
\hline Soluble calcium $\left(\mathrm{Ca}+{ }^{++}\right)$ & 6 meq/l \\
\hline Soil reaction $(\mathrm{pH})$ in 2.5 soil suspension & 8 & \\
\hline
\end{tabular}


The present experiment included 24 treatments, which were the combination of two planting date e.g. planting on $20^{\text {th }}$ Sept and $10^{\text {th }}$ Oct, three irrigation water level vis 50, 75 and $100 \% \mathrm{FC}$ and three foliar spray treatments i.e. $\mathrm{Ca}(1 \%$, wt/vol) as calcium chloride and/or boron $(60 \mathrm{ppm}$ as boric acid), besides the control (unsprayed treatment). The assessed treatments were arranged in a split - split plot design with three replicates. The planting dates were represented in the main plots, sub plots were assigned for irrigation levels and $\mathrm{Ca}$ and/or $\mathrm{B}$ foliar sprays and control treatments were randomly distributed in the sub - sub plots.

The experimental unit area was $14.7 \mathrm{~m}^{2}$ containing three ridges with $7 \mathrm{~m}$ length and $70 \mathrm{~cm}$ apart, and the potato seeds (Solanum tuberosum L. Mondial cv) were sown at $20 \mathrm{~cm}$ in between. One ridge was used to measure the morphological and physiological traits and the other two ridges were left for yield determinations. In addition, one ridge was left as buffer zone between each two experimental units to avoid lateral seepage of irrigation water. All the agronomic practices recommended for potato production in the area e.g. seed - bed preparation, N, P \& K fertilization, weed and pest control etc., were executed. Calcium chloride and boric acid were sprayed three times in two 2- week interval, and started 45 days after planting using a manual atomizer.

The irrigation water was added each three weeks intervals beginning at $10^{\text {th }}$ and $30^{\text {th }}$ October (20 days after planting) and ended $5^{\text {th }}$ and $25^{\text {th }}$ Jun. (15 days before harvesting) in the $1^{\text {st }}$ and $2^{\text {nd }}$ seasons, respectively. Under the adopted irrigation treatments, four irrigation events plus the planting one were applied throughout the entire growing season. To determine water quantity required under each adopted irrigation level, a soil sample (up to 60 $\mathrm{cm}$ depth) was taken before each irrigation from 100\% FC treatment, and soil moisture content $(\%, \mathrm{wt} / \mathrm{wt}$ basis) was calculated. The water quantity required to refill the $60 \mathrm{~cm}$ of soil profile to field capacity could be determined as follows:

Water required, $\mathrm{mm}=\mathrm{FC}-\mathrm{MC} \times \mathrm{Bd} x$ soil layer depth $(600 \mathrm{~mm}) / 100$ Where: $\mathrm{FC}=$ Soil field capacity $\%$ by weight $(\mathrm{g}), \mathrm{MC}=$ Soil moisture content $\%$ by weight before irrigation $(\mathrm{g}), \mathrm{Bd}=$ Bulk density of $60 \mathrm{~cm}$ depth, $\mathrm{gcm}^{-3}, 600=$ depth of root zone, $\mathrm{mm}$.

Then, multiplying water quantity required for $100 \%$ FC level by 0.75 and 0.50 to attain water quantities required for 75 and $50 \% \mathrm{FC}$, respectively. 
On applying the pre-determined water quantity, a plastic tube (spile) with internal diameter of 3 inches was used to apply and calculate the water quantity according to Michael (1987) as follows:

Water quantity, $\mathrm{cm}^{3} \mathrm{sec}^{-1}=0.61 \times \mathrm{A} \sqrt{ } 2 \times 981 \times \mathrm{h}$

Where: $\mathrm{A}=$ sectional tube area, $\mathrm{cm}^{2}$ and $\mathrm{h}=$ Effective water head over the tube, $\mathrm{cm}$.

\section{Data Recorded}

Yield determinations were recorded at harvesting time.

1. Yield and its components: It included of tubers №plant ${ }^{-1}$, tuber yield plant

${ }^{1}(\mathrm{~kg})$, average tuber weight $(\mathrm{g})$, total tuber yield (ton $\mathrm{fed}^{-1}$ ) and the relative yield increase (\%).

2. Cracking percentage: was calculated as number of cracking tubers per plot

3. Tuber quality: Tuber quality included: Nitrogen, $\mathrm{P}$ and $\mathrm{K} \%$ were determined according to AOAC (1990). Boron was determined calorimetrically using azomethine $-\mathrm{H}$ method as described by Bingham (1982), soluble calcium was determined according to Cottenie et al. (1982), and Total Hydrolysable Carbohydrates (THC) was determined using picric acid method according to Thomes and Dutcher (1924).

4- Dry matter (\%) : It was determined by drying $100 \mathrm{~g}$ of grated tuber tissues at $70{ }^{0} \mathrm{C}$ till the constant weight, and then DM \% was calculated.

The collected data were subjected to statistical analyses of variance according to Snedecor and Cochran (1980), and means separation was done using LSD at $5 \%$ probability level.

\section{RESULTS AND DISCUSSION}

\section{Yield and its components}

\subsection{Effect of planting date}

Data in Table 1 clear out that planting dates had significant effect on potato yield and its components and tuber cracking\% as well, except tubers №plant ${ }^{-1}$ in $1^{\text {st }}$ and $2^{\text {nd }}$ seasons. Planting potato on $10^{\text {th }}$ Oct gave higher total tuber yield than that attained with $20^{\text {th }}$ Sep by 18.14 and $9.81 \%$, respectively, in $1^{\text {st }}$ and $2^{\text {nd }}$ seasons. Similar trends were observed for yield components i.e. average tuber weight and tuber yieldplant ${ }^{-1}$, where the increases under planting at $10^{\text {th }}$ Oct reached to (22.54 and $\left.18.32 \%\right)$ and (17.04 and $\left.16.82 \%\right)$ 
for the abovementioned traits higher than those recorded with planting at $20^{\text {th }}$ Sep, respectively, in $1^{\text {st }}$ and $2^{\text {nd }}$ seasons. In this concern, Lerna and Mauromicale (2006) stated that potato tubers yield and quality are affected due to several factors including environmental conditions. As for tuber cracking\%, the trend was reversed, where cracking\% were increased under planting at $20^{\text {th }}$ Sep by 5.28 and $9.16 \%$ in $1^{\text {st }}$ and $2^{\text {nd }}$ seasons, respectively, comparable with planting at $10^{\text {th }}$ Oct. The present results are referred that the prevailing weather conditions of $10^{\text {th }}$ Oct planting date may be encouraged potato vegetative growth, which reflected on higher figures of average tuber weight and tuber yieldplant ${ }^{-1}$ and total tuber yield as well, comparable with $20^{\text {th }}$ Sep planting date. Perumal (1981) stated that temperature is the most dominating factor in yield contribution of potato, and the required temperatures during vegetative as well as reproductive growth phase might have contributed towards getting better vegetative growth and higher yield. In connection, Khan et al. (2011), Sandhu et al. (2013), Thongam et al. (2017) and Dash et al. (2018) reported that there were significant differences between planting dates regarding yield and its components of potato. Data reveal that the relative yield increases were higher and comprised 18.14 and $9.81 \%$ with planting at $10^{\text {th }}$ Oct as compared with planting at $20^{\text {th }}$ Sep.

\subsection{Effect of irrigation level}

Data in Table 1 reveal that the assessed irrigation levels significantly affected yield and its components and tuber cracking as well in $1^{\text {st }}$ and $2^{\text {nd }}$ seasons. Irrigation at $100 \% \mathrm{FC}$ exhibited the highest values of tuber yield fed $^{-1}$, average tuber weight, tuber №plant ${ }^{-1}$, and tuber yieldplant ${ }^{-1}$. The increases in the abovementioned traits, under $100 \%$ FC level, were (68.97 and $22.40 \%)$, (25.36 and 10.94\%), (40.08 and 17.26\%) and (72.96 and $30.40 \%)$ in $1^{\text {st }}$ season and (60.52 and 19.11\%), (21.98 and 9.84\%), (42.11 and $17.82 \%)$ and $(71.20$ and $29.29 \%)$ in $2^{\text {nd }}$ season, compared with 50 and $75 \%$ FC, respectively. It evident from the obtained results, that the abovementioned traits were gradually reduced as irrigation level decreased and vice versa. In this regard, Belanger et al. (2002) registered a reduction in tubers bulking rate by $40 \%$ under water stress than normal irrigation condition, which causing a decline in tuber average weight. Furthermore, Badr et al. (2012), Al-Janaby (2012), Abubaker, et al. (2014) and Dash et al. (2018) found that increasing water quantities up to the highest levels enhanced potato yield and its components. In addition, data illustrate that 
irrigating potato crop at $75 \% \mathrm{FC}$ resulted in lower figures of tuber cracking disorder reached to 11.87 and $26.65 \%$ in $1^{\text {st }}$ season, and 14.79 and 24.43 in $2^{\text {nd }}$ season, than with 50 and $100 \%$ FC levels, respectively. In this concern, it is well known that the main reason for the development of deep cracks is irregular irrigation of the crop during the tuber enlargement stage. Following irregular growth due to drought, watering will bring about rapid rehydration of the vascular tissues. The resulting internal pressure will be greater than the resistance of the skin, which breaks and then heals. The obtained results proved that optimum irrigation conditions resulted in higher relative yield increases values under 75 and $100 \% \mathrm{FC}$ irrigation levels comprised 38.05 and $68.97 \%$ in $1^{\text {st }}$ season and 34.76 and $60.52 \%$, respectively, comparing with $50 \%$ FC irrigation level.

\subsection{Effect of $C a$ and/or $B$ foliar sprays}

Spraying potato plants with $\mathrm{Ca}$ and/or B significantly influenced yield and its components and tuber cracking as well, in $1^{\text {st }}$ and $2^{\text {nd }}$ seasons (Table 1$)$. It is obvious, in general, all the assessed $\mathrm{Ca}$ and/or B treatments surpassed the control regarding total tuber yield and its attributes. In addition, spraying potato crop with $\mathrm{Ca}+\mathrm{B}$ exhibited higher values of the tested traits, except tuber №plant ${ }^{-1}$ in $1^{\text {st }}$ season, where the highest figure (3.21) was recorded due to spraying $\mathrm{Ca}$, as compared with that recorded under spraying the crop with $\mathrm{Ca}+\mathrm{B}$ (3.18), however, the difference did not reach the significance level. The relative increases in the studied traits, except tuber №plant ${ }^{-1}$, due to spraying Ca+ B, comparable with the control comprised (53.62 and 60.52\%), (58.34 and 47.82\%) and $(64.71$ and $62.50 \%)$ in $1^{\text {st }}$ and $2^{\text {nd }}$ seasons for total tuber yield and yield attributes e.g. average tuber weight and tuber yieldplant ${ }^{-1}$, respectively. The current results are in parallel with those reported by El -Dissoky and Abdel Kadar ((2013), Chowdhury (2017), Simango and Walls (2017) and Singh et al. (2018) whom reported that potato yield and its components were increased by spraying the plants with $\mathrm{Ca}$ and/or boron as compared with the control (unsprayed plants). Regarding tuber cracking phenomenon, it is clear that the assessed $\mathrm{Ca}$ and/or $\mathrm{B}$ treatments resulted in favorite figures as compared with the control, and $\mathrm{Ca}+\mathrm{B}$ treatment was superior in this respect. The reduction in tuber cracking phenomenon, due to $\mathrm{Ca}+\mathrm{B}$ treatment, were 38.44 and $41.01 \%$ lower than those recorded with the control, respectively, in $1^{\text {st }}$ and $2^{\text {nd }}$ seasons. Data in Table1 illustrate that $\mathrm{Ca}+\mathrm{B}$ treatment still surpassed the other $\mathrm{Ca}$ and/or $\mathrm{B}$ treatments and the control as well to enhance relative yield increase parameter. 


\subsection{Effect of interactions}

\subsubsection{Effect of bi-lateral interaction of planting dates and irrigation levels}

It is obvious that bi-lateral interaction of planting dates and irrigation levels reflected a significant effect on yield and its components and tuber cracking $(\%)$ in $1^{\text {st }}$ and $2^{\text {nd }}$ seasons, Table 2 . Generally in $1^{\text {st }}$ and $2^{\text {nd }}$ seasons, bi-lateral interaction of planting on $10^{\text {th }}$ Oct and irrigation at $100 \% \mathrm{FC}$ level recorded the highest values of total tuber yield, average tuber weight, tuber yield plant ${ }^{-1}$, except tuber №plant ${ }^{-1}$ trait in $2^{\text {nd }}$, where the highest figure (3.321) was obtained due to $20^{\text {th }}$ Sep planting date as interacted with 100 $\% \mathrm{FC}$ irrigation level. In addition, relative yield increase values were enhanced due to bi-lateral interaction of planting on $10^{\text {th }}$ Oct and irrigation at100 \% FC level, in $1^{\text {st }}$ and $2^{\text {nd }}$ seasons. Regarding tuber cracking $\%$, desired figures were attained due to bi-lateral interaction of planting on $10^{\text {th }}$ Oct and $75 \% \mathrm{FC}$ irrigation level, in $1^{\text {st }}$ and $2^{\text {nd }}$ seasons.

\subsubsection{Effect of bi-lateral interaction of planting date and Ca and/or $B$ foliar sprays}

The bi- lateral interaction of planting on $10^{\text {th }}$ Oct and foliar spray with $\mathrm{Ca}+\mathrm{B}$ significantly increased potato tubers yield $\mathrm{fed}^{-1}$, average tuber weight and tuber yield plant ${ }^{-1}, 1^{\text {st }}$ and $2^{\text {nd }}$, Table 1 . In addition, such interaction exhibited higher values of the abovementioned traits, except, tuber № plant ${ }^{-1}$ in $1^{\text {st }}$ season, where higher values ( 3.37 and 3.02 , respectively, $1^{\text {st }}$ and $2^{\text {nd }}$ ) were recorded due to $20^{\text {th }}$ Sep planting date as interacted with spraying Ca treatment, without significant differences in $1^{\text {st }}$ and $2^{\text {nd }}$ seasons. Favorite tuber cracking\% and higher relative yield increase values were obtained under planting on $10^{\text {th }}$ Oct and $\mathrm{Ca}+\mathrm{B}$ foliar spray, in $1^{\text {st }}$ and $2^{\text {nd }}$ seasons.

\subsubsection{Effect of bi-lateral interaction of irrigation levels and $\mathrm{Ca}$ and/or $\mathrm{B}$ foliar sprays}

Data in Table 3 exhibited that bi- lateral interaction of irrigation levels and foliar spray with $\mathrm{Ca}$ and/or B significantly altered potato yield and its attributes and tuber cracking $\%$, in $1^{\text {st }}$ and $2^{\text {nd }}$ seasons. Bi- lateral interaction of irrigation at100 \% FC level and $\mathrm{Ca}+\mathrm{B}$ foliar spray exhibited higher figures of total tuber yield, average tuber weight and tuber yield plant ${ }^{-1}$, and relative yield increase $\%$ as well, in $1^{\text {st }}$ and $2^{\text {nd }}$ seasons. Furthermore, it is observed that tuber № plant ${ }^{-1}$ and tuber cracking\%, exhibited different trend to each other, and to the other studied traits as well. Tuber № plant ${ }^{-1}$ exhibited higher values under irrigation at $100 \% \mathrm{FC}$ 
level as interacted with $\mathrm{Ca}$ spray, whereas lower tuber cracking\% values were attained with interaction of irrigating at $75 \% \mathrm{FC}$ and $\mathrm{Ca}+\mathrm{B}$ foliar spray, in $1^{\mathrm{st}}$ and $2^{\text {nd }}$ seasons.

\subsubsection{Effect of tertiary interaction of planting dates, irrigation levels and Ca and/or B foliar sprays}

The tertiary interaction of planting dates, irrigation levels and $\mathrm{Ca}$ and/or B foliar sprays reflected a significant effect on potato yield and its components besides cracking percentage in $1^{\text {st }}$ and $2^{\text {nd }}$ seasons, however, the studied parameters exhibited different response, (Table 4). Higher total potato tubers yield values were attained with planting at $10^{\text {th }}$ Oct, irrigation at75\% FC level and sprayed potato plants with $\mathrm{Ca}+\mathrm{B}$ interaction, in $1^{\text {st }}$ and $2^{\text {nd }}$ seasons. Average tuber weight exhibited the highest figure with planting at $10^{\text {th }}$ Oct, irrigation at $75 \%$ FC level and sprayed potato plants with $\mathrm{Ca}+\mathrm{B}$ interaction in $1^{\text {st }}$ season, whereas in $2^{\text {nd }}$ season the highest value resulted from planting at $10^{\text {th }}$ Oct, irrigation at $100 \% \mathrm{FC}$ level and sprayed potato plants with $\mathrm{Ca}+\mathrm{B}$ interaction. Tuber № plant $^{-1}$ exhibited higher values under the interaction of planting on $20^{\text {th }} \mathrm{Sep}$, irrigation at $100 \% \mathrm{FC}$ level and $\mathrm{Ca}$ spraying in $1^{\text {st }}$ and $2^{\text {nd }}$ seasons. Tuber yield plant ${ }^{-1}$ shows higher values with planting at $10^{\text {th }}$ Oct, irrigation at $100 \%$ FC level and control(without spray) interaction in $1^{\text {st }}$ season, and interaction of planting at $10^{\text {th }}$ Oct, irrigation at $100 \%$ FC level and sprayed potato plants with $\mathrm{Ca}+\mathrm{B}$ in $2^{\text {nd }}$ season. As for tuber cracking\%, the highest values were obtained due to planting at $20^{\text {th }} \mathrm{Sep}$, irrigation at $100 \% \mathrm{FC}$ level and sprayed potato plants with $\mathrm{Ca}+\mathrm{B}$ interaction, in $1^{\text {st }}$ and $2^{\text {nd }}$ seasons. Relative yield increase $\%$, in $1^{\text {st }}$ and $2^{\text {nd }}$ seasons, reveal higher values due to planting at $10^{\text {th }}$ Oct, irrigation at $75 \% \mathrm{FC}$ level and sprayed potato plants with $\mathrm{Ca}+\mathrm{B}$ interaction.

\section{Tuber Quality}

\subsection{Effect of planting date}

Planting dates had significant effect on tuber content of $\mathrm{N}, \mathrm{Ca}$, boron, total carbohydrates and DM percentages in $1^{\text {st }}$ and $2^{\text {nd }}$ seasons, Table 5 . The increases in $\mathrm{N}, \mathrm{Ca}$, boron, total carbohydrates and $\mathrm{DM} \%$, due to planting at $10^{\text {th }}$ Oct, were higher than those recorded under $20^{\text {th }}$ Sep planting date by (4.10 and 6.54\%), (29.20 and $27.71 \%)$, (48.28 and 49.10\%), (4.94 and $3.60 \%)$ and $(10.39$ and $8.12 \%)$ in $1^{\text {st }}$ and $2^{\text {nd }}$ seasons, respectively, comparing with $20^{\text {th }}$ Sep planting date. Nevertheless, $\mathrm{P}$ and $\mathrm{k}$ contents exhibited reversed 
trend, where higher values were recorded with $20^{\text {th }}$ Sep planting date, however, the differences did not the significance level. In connection, Sandhu et al. (2013), Thongam et al. (2017) and Dash et al. (2018) found that differed planting dates induced variations with respect to potato tubers quality.

\subsection{Effect of irrigation levels}

Data in Table 5 show that, tuber contents of $\mathrm{N}, \mathrm{Ca}$, boron, total carbohydrates and DM percentages were significantly affected due to the adopted irrigation levels in $1^{\text {st }}$ and $2^{\text {nd }}$ seasons. Higher figures for the abovementioned quality traits were registered under irrigation at $100 \% \mathrm{FC}$, compared to 50 and $75 \% \mathrm{FC}$, which reached to $(7.84$ and $5.10 \%),(29.44$ and $11.67 \%),(75.00$ and $24.66 \%),(4.00$ and $0.21 \%)$ and $(2.29$ and $0.81 \%)$ in $1^{\text {st }}$ season. The corresponding increases in $2^{\text {nd }}$ season were $(5.81$ and $4.46 \%)$, (31.52 and 10.65\%), (87.86 and $28.75 \%),(2.07$ and 2.97\%) and (5.52 and $4.44 \%$ ), respectively, comparing with 50 and $75 \% \mathrm{FC}$ levels. In this concern, Ahmadi et al. (2010) stated that water stress at any growth stage leads to a considerable negative impact on potato tuber quality. In addition, El Saidi et al. (2010) and Dash et al. (2018) indicated that tuber quality of potato were improved with increasing irrigation water quantities up to the highest levels.

\section{3 . Effect of Ca and/or B foliar spray}

Spraying potato plants with $\mathrm{Ca}$ and/or $\mathrm{B}$ significantly affected all the investigated parameters of potato tuber quality $1^{\text {st }}$ and $2^{\text {nd }}$ seasons, Table 6 . The highest values of $\mathrm{N}(26.90$ and $27.01 \%), \mathrm{P}(34.42$ and $33.07 \%), \mathrm{K}(16.96$ and $16.96 \%), \mathrm{Ca}(35.65$ and $28.90 \%)$ and $\mathrm{B}(34.00$ and $38.20 \%)$ and $\mathrm{DM} \%($ 19.45 and $20.04 \%$ ), respectively, in potato tubers were obtained due to spraying with $\mathrm{Ca}+\mathrm{B}$, in $1^{\text {st }}$ and $2^{\text {nd }}$ seasons, comparable with the control. The total carbohydrates increases were 12.07 and $10.10 \%$, in $1^{\text {st }}$ and $2^{\text {nd }}$ seasons, due to spraying with $\mathrm{B}$, comparable with the control. In connection, Follett et al., 1981 stated that enhancement in tuber quality by foliar application of boron may be attributed to stimulating plant biological activities such as photosynthesis, enzyme activities, nutrient uptake and rate of photo-assimilates translocation into the tuber. In addition, Awad et al. (2010), Jafari et al. (2013) and Tantawy et al. (2017) found that sprayed potato plants with $\mathrm{Ca}$ and / or boron resulted in higher tuber quality values more than unsprayed ones. 


\subsection{Effect of interactions}

2.4.1. Effect of bi-lateral interaction of planting dates and irrigation levels

Data in Table 6 show that the bi-lateral interaction of planting dates and irrigation levels significantly influenced all the studied potato tuber quality parameters, except $\mathrm{P} \%$ in $2^{\text {nd }}$ season and $\mathrm{K} \%$ in $1^{\text {st }}$ and $2^{\text {nd }}$ seasons. Planting on $10^{\text {th }}$ Oct date as interacted with irrigating at $100 \%$ FC exhibited higher figures of $\mathrm{N}, \mathrm{Ca}, \mathrm{B}$ and both total carbohydrates and DM percentages, $1^{\mathrm{st}}$ and $2^{\text {nd }}$ seasons, whereas, $\mathrm{P} \%$ reveal higher values with planting on $20^{\text {th }}$ Sep and irrigating at $75 \%$ FC level bi-lateral interaction in $1^{\text {st }}$ season, and under planting on $20^{\text {th }}$ Sep and irrigating at $100 \%$ FC bi-lateral interaction, in $2^{\text {nd }}$ season.

\subsubsection{Effect of bi- lateral interaction of planting dates and Ca and/or B foliar sprays}

The bi-lateral interaction of planting dates and $\mathrm{Ca}$ and/or B foliar sprays significantly altered all the studied potato tuber quality traits, in $1^{\text {st }}$ and $2^{\text {nd }}$ seasons, Table 6. Planting on $10^{\text {th }}$ Oct date as interacted with $\mathrm{Ca}+\mathrm{B}$ foliar spray resulted in higher figures of the investigated potato quality traits, except total carbohydrates and DM percentages, which exhibited higher values due to planting on $10^{\text {th }}$ Oct date as interacted with Boron foliar spray and bi-lateral interaction of planting on $10^{\text {th }}$ Oct date and $\mathrm{Ca}+\mathrm{B}$ foliar spray, respectively, $1^{\text {st }}$ and $2^{\text {nd }}$ seasons.

\subsubsection{Effect of bi- lateral interaction of irrigation levels and $\mathrm{Ca}$ and/or $B$ foliar sprays}

Data in Table 7 reveal that bi-lateral interaction of irrigation levels and $\mathrm{Ca}$ and/or Boron foliar sprays significantly affected all the potato tuber quality traits under study, in $1^{\text {st }}$ and $2^{\text {nd }}$ seasons. Irrigating at $100 \%$ FC level and $\mathrm{Ca}+\mathrm{B}$ foliar spray exhibited higher values of the investigated potato quality traits, except, total carbohydrates, which exhibited higher values with irrigating at $100 \%$ FC level and Boron foliar spray interaction, in $1^{\text {st }}$ and $2^{\text {nd }}$ seasons.

\subsubsection{Effect of tertiary interaction of planting dates, irrigation level and Ca and/or B foliar sprays}

The tertiary interaction of planting dates, irrigation levels and $\mathrm{Ca}$ and/or B foliar sprays significantly affected all the investigated potato quality traits, except tuber $\mathrm{P} \%$ content, in $1^{\text {st }}$ and $2^{\text {nd }}$ seasons, Table 8 . In addition, higher 
values of $\mathrm{N} \&, \mathrm{~K} \%, \mathrm{Ca}, \mathrm{B}$ and $\mathrm{DM} \%$ were obtained due to planting on $10^{\text {th }}$ Oct, irrigating at $100 \% \mathrm{FC}$ and spraying potato plants with $\mathrm{Ca}+\mathrm{B}$ interaction, whereas total carbohydrates\% was the highest under interaction of planting on $10^{\text {th }}$ Oct, irrigation levels at $100 \%$ FC and sprayed plants with Boron, in $1^{\text {st }}$ and $2^{\text {nd }}$ seasons.

Conclusively, at similar experimental conditions it could be concluded that , the tertiary interaction of planting on $10^{\text {th }}$ Oct, irrigation at $100 \%$ FC level and sprayed potato plants with $\mathrm{Ca}+\mathrm{B}$ was the proper for enhancing tuber yield and improved quality. In addition, for reducing tuber cracking disorder, planting on $10^{\text {th }}$ Oct, irrigation at $75 \% \mathrm{FC}$ and spraying potato plants with $\mathrm{Ca}$ $+\mathrm{B}$ is the recommended interaction.

\section{REFERENCES}

A.O.A.C. Association of Official Agricultural Chemists.(1990). Official methods of analysis. $10^{\text {th }}$. Ed. A.O.A.C., wash., D.c

Abu Baker, B. M. A. Y. ShuAng-En, S. GuAng-Cheng,M. AlhAdi and A. El Siddig (2014). Effect of irrigation levels on the growth, yield and quality of potato. Bulgarian J. Agric. Sci., 20 (No 2): 303-309.

Ahmadi, S.H., M.N. Andersen, F. Plauborg, R.T. Poulsen, C.R. Jensen, A.R. Sepaskhah and S. Hansen. 2010. Effects of irrigation strategies and soils on field grown potatoes: Yield and water productivity. Agric. Water Managem., 97(11): 1923-1930.

Al-Janaby M.A.A.F. (2012). Effect of drip irrigation, organic manure and mulching on growth and yield of potato (Solanum tuberosum L.). Ph D. Thesis. Fac. Agric. Univ. Baghdad. Pp 133.

Awad, El. M.M.; M.S. Emam and Z. S. El. Shall (2010). The influence of foliar spraying with nutrients on growth, yield and storability of potato tubers. J. Plant Prod., Mansoura Univ., 1 (10): 1313-1325.

Badr, M. A., El-Tohamy, W. A., and Zaghloul, A. M. 2012. "Yield and Water Use Efficiency of Potato Grown under Different Irrigation and Nitrogen Levels in an Arid Region.” Agricultural Water Management, 110: 9-15.

Belanger, G., Walsh, J. R., Richards, J. E., Milburn, P. H., and Ziadi, N. (2002). Nitrogen Fertilization and Irrigation Affects Tuber Characteristics of Two Potato Cultivars. Amer. J. Potato Res., 79 (4): 269-79. 
Bingham, F.T. (1982). Boron in Al. Page R.H. Miller and D.R. Keeny (eds). Methods of soil analysis, part 2, Agron. Monogr. G. Am. Soc. Agron., Madison, Wip.431-446.

Cantorea, V., F. Wassarb , S.S. Yamaçb , M.H. Sellamic, R. Albrizioc , A.M. Stellaccid , M. Todorovicb (2014). Yield and water use efficiency of early potato grown under different irrigation regimes. International Journal of Plant Production, 8(3): 409- 428.

Chapman, H.D. and P.F. Pratt (1961). Method Of Analysis For Soils, Plant And Water. Univ. Cal . Dir. Agric. Sci., USA, Pp. 150-152.

Chowdhury R.S. (2017). Effect of calcium, magnesium, sulphur, zinc and boron on growth and yield of potato (cv. Kufri Jyoti). M.Sc thesis, Fac. Hort. Uttar Banga Krishi Viswavidyalaya.

Cottenie , A., M. Verso, L. Kiekens, G. Velghe and R.Gamerlynck (1982). Chemical Analysis Of Plant And Soils. Lab of Analytical Agronomy state University, Chent-Belgium.

Dash S.N., Y. Pushpavathi and S. Behera (2018). Effect of Irrigation and Mulching on Growth, Yield and Water Use Efficiency of Potato. Int. J. Curr. Microbiol. App. Sci., 7(2): 2582-2587.

EI Saidi, M.T., O.M. Kassab, E.M. Okasha and A.R.E. Abdelghany (2010). Effect of drip irrigation systems, water regimes and irrigation frequency on growth and quality of potato under organic agriculture in sandy soils. Aust. J. Basic Appl.Sci., 4(9): 4131-4141.

El-Dissoky R.A. and A.E.S. Abdel-Kadar (2013). Effect of Boron as a Foliar Application on Some Potatoes Cultivars Under Egyptian Alluvial Soil Conditions. Res. J. Agric.Bio. Sci., 9(5): 232-240.

Erdem, T.; Yesim Erdem; H. Orta; H. Okursoy (2006). Water -yield relationships of potato under different irrigation methods and regimens. Sci. Agric. (Piracicaba, Braz.), 63(3):226-231.

Farrag, K., M. A. A. Abdrabbo and S. A. M. Hegab (2016). Growth and Productivity of Potato under Different Irrigation Levels and Mulch Types in the North West of the Nile Delta, Egypt. Middle East Journal of Applied Sciences, 6 (04):774-786

Follett R.H.; K.S. Murphy and R.L. Donahue (1981). "Fertilizers and Soil Amendments". Prentice- Hall, New Jersey.

Gumede, T. (2017). Influence of calcium on yield and quality aspects of potatoes (Solanum tuberosum L.) MSc in Agriculture (Agronomy) at the Faculty of AgriSciences at Stellenbosch University. 
Jafari, J. S., A. H. Shiranirad , J. Daneshian and A. Rokhzadi (2013). Effects of nitrogen application and spraying of boron and manganese on growth traits of two potato cultivars. Inter J. Biosciences, 3 (9): 298-303.

Khan A.A., M.S. Jilani, M.Q.Khan and M. Zakhir (2011). Effect of seasonal variation on tuber bulking rate of potato. J. Animal and Plant Sci.; 21(1):31-37.

Kleinhenz M.D., J.P. Palta (2002). Root zone calcium modulates the response of potato plants to heat stress. Physiologia Plantarum, 115: 111-8.

Lerna, A. and G. Mauromicale (2006). Physiological and growth response to moderate water deficit of off- season potatoes in the Mediterranean environment. Agric. Water Management. 82 (1-2):193-209.

Levy, D., Coleman, W.K., Veilleux, R.E. (2013). Adaptation of Potato to Water Shortage: Irrigation Management and Enhancement of Tolerance to Drought and Salinity. Am. J. Potato Res. DOI 10.1007/s12230-012-9291-y.

Michael, A.M. (1978). Irrigation: Theory and Practices. Vikas Publishing House, Delhi.

Palta J.P. (1996). Role of calcium in plant responses to stresses: Linking basic research to the solution of practical problems. Proceedings of Colloquium: Recent advances in plant responses to stress: bridging the gap between science and technology. Hort. Sci., 31: 51-57.

Perumal N.K. (1981). Influence of date of planting on the growth, development and yield of potato. Journal of Root Crops., 7(1, 2):33-36.

Piper, C.S. (1938). The occurrence of reclamation Disease in cereals in south Australia, Australia Council Sci. ind. Research Pamphlet No.78:24-28

Piper, C.S. (1950). Soil And Plant Analysis. Inter. Sci. Publishers, Inc., New York. Inter Sci. Publishers, inc., New York.

Sandhu A.S., S.P.Sharma, R.D. Bhutani and S.C. Khurana (2013). Potato (Solanum tuberosum L.) tuber yield as affected by planting times and fertilizer doses under sandy loam soils. Indian J. Agric. Res., 47: 496-502.

Simango. K., and J.E.V. Walls (2017). Effects of Different Soil Treatments on the Development of Spongospora subterranean. sp. subterranea in Potato Roots and Tubers in the Greenhouse. European Association for Potato Research. 60:47-60.

Singh, S.K., M. Sharma, K.R. Reddy and T. Venkatesh (2018). Integrated application of boron and sulphur to improve quality and economic yield in potato. J. Environ. Bio., (39): 204-210. 
Snedecor, G.W. and W.G. Cochran. (1980). Statistical Methods. $7^{\text {th }}$ ed., Iowa State Univ., Press, Ames., Iowa, U.S.A.

Tantawy, A. S., Y.A. Salama, S. A. Saleh and A. A. Ghoname (2017). Enhancing yield and quality of two potato cultivars by using boron foliar Application. Middle East J. Appl. Sci., 7 (3): 510-518.

Thomas, W. and R. A. Dutcher (1924). The colorimetric determination of carbohydrates in plants by the picric acid reduction method. The estimation of reducing sugars and sucrose. J. Am. chem. Soc., 46:1662-I 669.

Thomes, M. and R. A. Dutcher (1924). The calorimetric determination of $\mathrm{CHO}$ in plants by the picric acid reduction method. J. Amer. Chem. Soc., 46:7-12.

Thongam, B., A.S. Kadam, A.A. Singh and Y. H. Singh. (2017). Influence of planting dates on growth and yield of potato (Solanum tuberosum L.). J. Pharmacognosy and Phytochemistry, 6 (6): 1243-1246.

Walkley, A. (1947). A critical examination of a rapid method for determined organic carbon in soils. Effect of variation indigestion conditions and in organic soil constituents. Soil Sci., 63:246-251.

Wright, C.H. (1939). Soil Analysis. Thom as murby and Co., London.

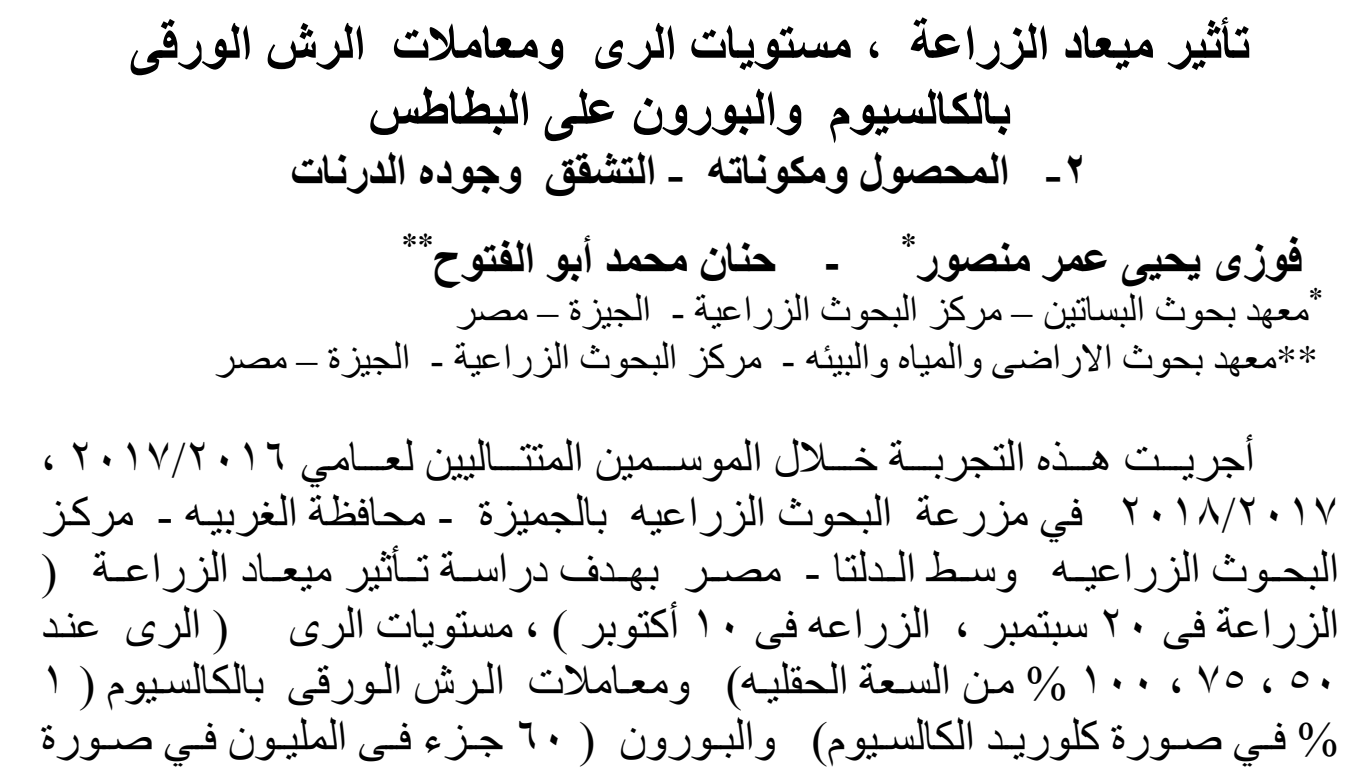




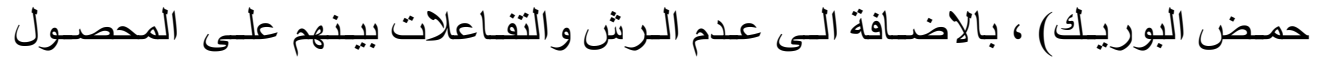

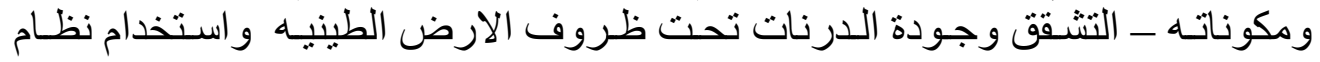

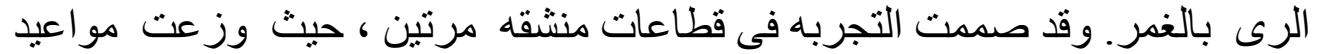

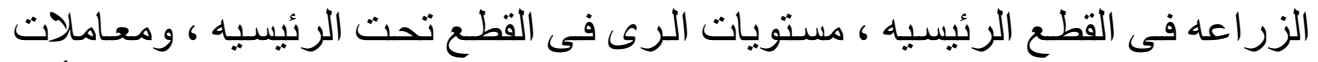

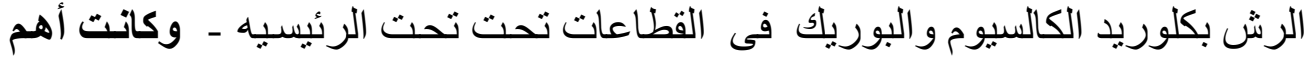
النتائج المتحصل عليها كالتالى : التوريد

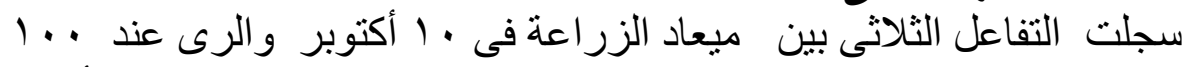

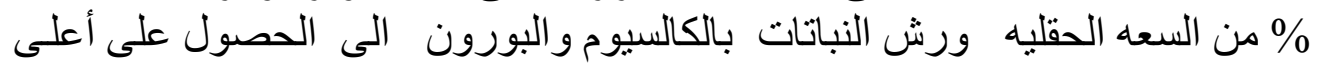

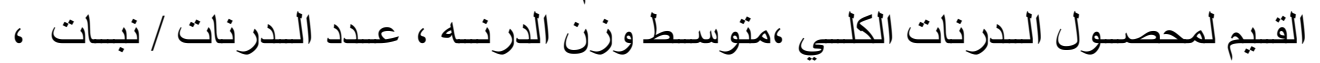

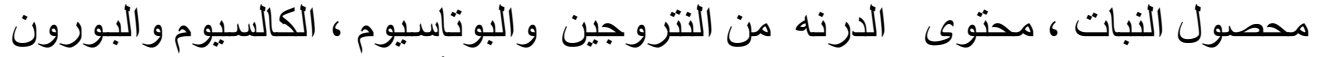

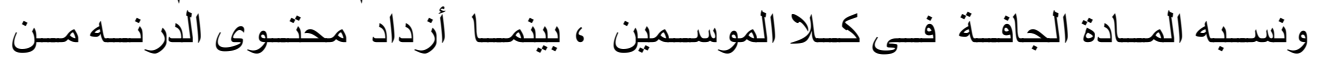

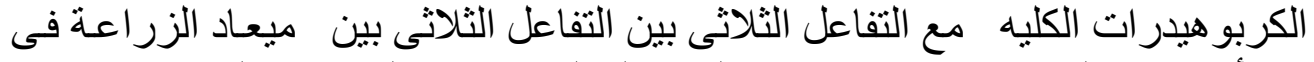

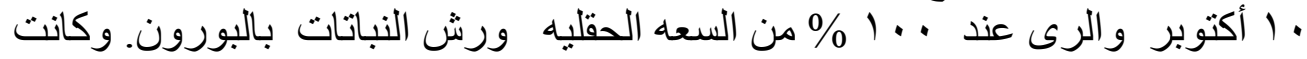

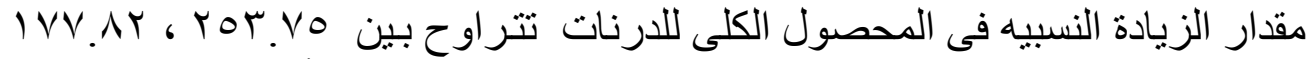

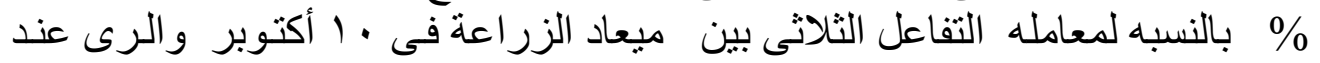

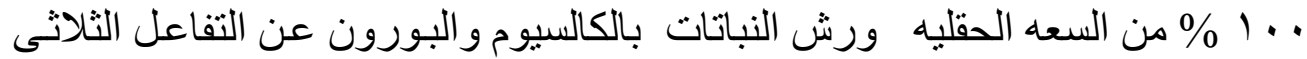

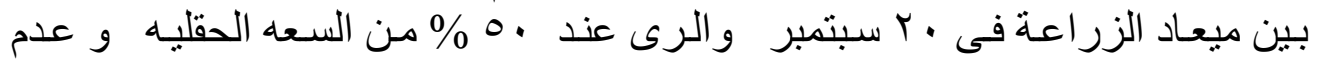

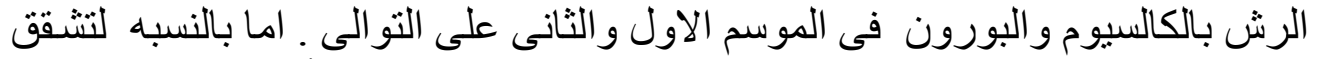

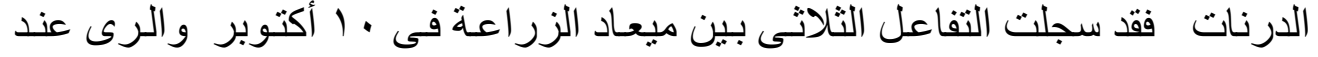

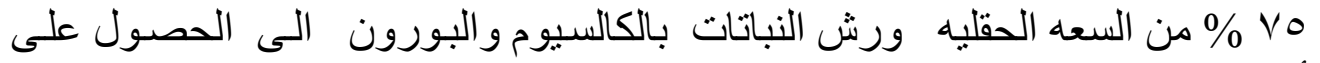

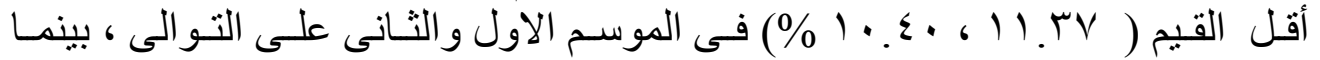

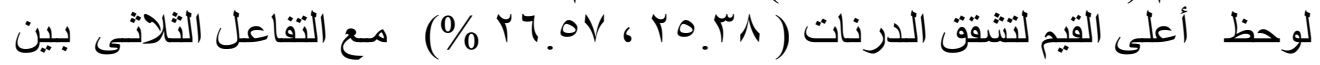

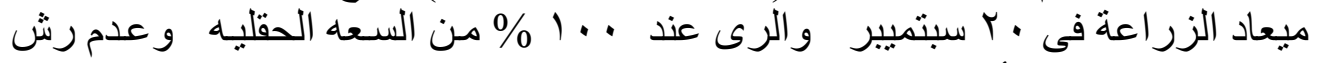

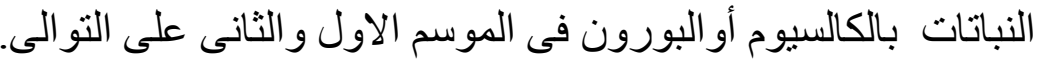

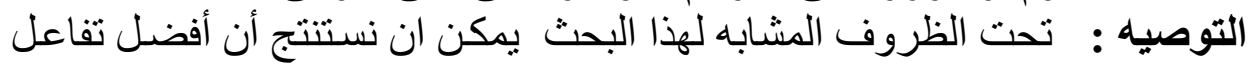

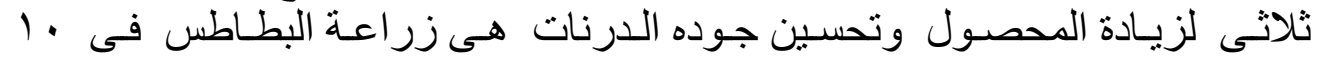

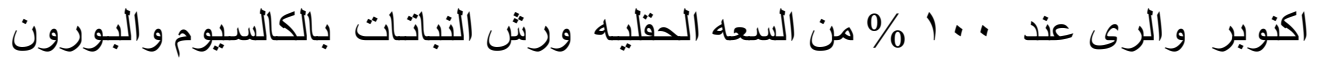

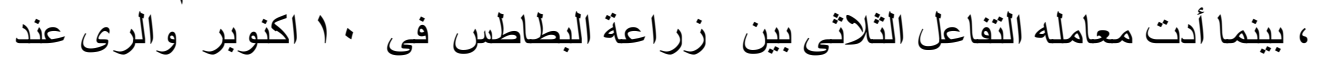

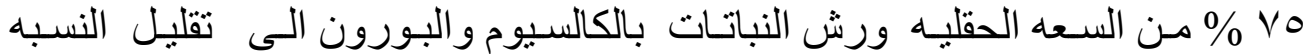
المئويه لتشقق الدرنات. 